Journal of Business School
2018, $1(1): 30-44$
DOI: $10.29226 / \mathrm{TR} 1001.2018 .64$
Journal Homepage: $\underline{\text { https://www.journalbusiness.org }}$

\title{
Capital Investment and Manufacturing Productivity: The Case of Nigeria
}

\author{
David Bunaebi Sese \\ Department of Economics, Niger Delta University, Wilberforce Island, Nigeria, \\ sesevid@gmail.com \\ Francis Agboola Oluleye \\ Department of Economics and Development Studies, Federal University Otuoke, Nigeria, \\ francisoluleye@yahoo.com
}

\begin{abstract}
This paper examined the extent to which the manufacturing sector has been productive due to the level of capital investment in the sector. In effort to achieve the goal of this study, data ranging from the first quarter of the year 2011 to the fourth quarter of the year 2016 was used. Literature shows that the manufacturing sector is faced with so many challenges that affects its level of performance. The position of the literature was confirmed by the efficiency analysis conducted by the study. The partial efficiency analysis conducted in this paper used the input-output mathematical programming approach. The input here is capital investment (foreign capital inflow and bank credit to manufacturing sector) and output is the contribution of the manufacturing sector to gross domestic product. It was found that the sector was generally unproductive as a good efficiency score was only recorded during few quarters. Moreover, it was also found that the unproductive trend in the manufacturing sector tend to have continue to deteriorate to date as shown by the efficiency rank score presented by the order-m efficiency analysis result. This paper therefore recommends appropriate policy capable of providing the manufacturing sector with the enabling environment to thrive better and performance at optimum.
\end{abstract}

Keywords: Capital investments, Manufacturing Sector, Efficiency, Productivity, Input-Output 


\section{Introduction}

Prolonged economic recession occasioned by the collapse of the world oil market from the early 1980 and the attendant sharp fall in foreign exchange earnings have adversely affected economic growth and development in Nigeria. Other problems of the economy include excessive dependence on imports for both consumption and capital goods, dysfunctional social and economic infrastructure, unprecedented fall in capacity utilization rate in industry and neglect of the agricultural sector, among others. These have resulted in fallen incomes and devalued standards of living amongst Nigerians. Although the structural adjustment programme (SAP) was introduced in 1986 to address these problems, no notable improvement has taken place. From a middle-income nation in the 1970s and early 1980s, Nigeria is today among the 30 poorest nations in the world. Putting the country back on the path of recovery and growth will require urgently rebuilding deteriorated infrastructure and making more goods and services available to the citizenry at affordable prices. This would imply a quantum leap in output of goods and services.

The path to economic recovery and growth may require increasing production inputs - land, labour, capital and technology - and or increasing their productivity. Increasing productivity should be the focus because many other countries that have found themselves in the same predicaments have resolved them through productivity enhancement schemes. For instance, Japan from the end of the World War II and the United States of America from the 1970s have made high productivity the centre point of their economic planning and the results have been resounding. Also, middle income countries like Hong Kong, South Korea, Singapore, the Philippines, India, Mexico and Brazil have embraced boosting productivity schemes as an integral part of their national planning and today they have made significant in-roads into the world industrial markets.

Given the importance of high productivity in boosting economic growth and the standards of living of the people, its measurement cannot but be of importance to both policy makers and researchers. Productivity measurement can be used to evaluate the efficiency of an economy in relation to others. It will also be useful in ascertaining the relative efficiency of firms, sub-sectors and sectors. Knowledge of the relative efficiency of industries and their profitability could aid government in planning its programmes and policies, especially in deciding on which industries should be accorded priority. In addition, it will help the government in deciding the wage level as the input and output of labour will be well quantified.

At the micro level, productivity measurement will, among others, aid production planning and sales, especially in checking cost, including wages, substitution of factors of production, reduction of wastes, etc.

In view of the foregoing, the objective of this paper is to attempt a review of the level of productivity in Nigeria's manufacturing sector over the years based on the level of capital investment in the sector. The paper is divided into five sections. Following the introduction, Section II (i.e. Literature Review) reviews the concept and measurement of productivity, productivity in the Nigerian manufacturing industry, identified constraints, and necessary conditions for achieving high productivity in industry. Sections III and IV are dedicated to the method of research and presentation and discussion of results respectively. Lastly, Section V concludes the paper. 


\section{Literature Review}

\subsection{The Concept and Measurement of Productivity}

\section{Concept of Productivity}

Enterprises produce goods and services for sale with the aim of making returns on their investments. The goods and services are the output of the enterprises. In the process of production, an enterprise makes use of scarce resources which are called factors of production, namely land, labour and capital. These factors of production are generally referred to as inputs in the production process and their owners are rewarded from the returns generated by the enterprise. How to combine the inputs to have a maximum result - greatest output with a given input - is the problem of productivity. Unfortunately, there is no universal definition of the term, productivity. It has been defined by Economists as the ratio of output to input in a given period of time. In other words, it is the amount of output produced by each unit of input. Business Managers, on the other hand, see productivity not only as a measure of efficiency, but also connotes effectiveness and performance of individual organizations. For them, productivity would incorporate quality of output, workmanship, adherence to standards, absence of complaints, customer satisfaction, etc (Udo-Aka, 1983).

The administrator is more concerned with organizational effectiveness, while the industrial engineer focusses more on those factors which are more operational and quantifiable, work measurement and performance standards (Adekoya, 1989). Productivity can be computed for a firm, industrial group, the entire industrial sector or the economy as a whole. It measures the level of efficiency at which scarce resources are being utilised. Higher or increasing productivity will, therefore, mean either getting more output with the same level of input or the same level of output with less input. Let us look at the sub-concepts.

Total-Factor Productivity: This is the ratio of output to the aggregate measure of the inputs of all the factors of production. Theoretically, this is the true measure of productivity as it incorporates the contribution of all the factor inputs.

Partial Productivity: There are many problems that are associated with measuring total-factor productivity. For example, it is difficult to construct an index number that will serve as the input. It will mean adding hours done by labour to units of investments, the contributions of land, technology, etc. to get a single index. Even to quantify them all in monetary terms is very cumbersome. The construction of total-factor productivity index is, therefore, not appealing. In its place, therefore, partial productivity is used. This estimates the ratio of total output to a single input, usually labour. In most discussions, especially in economics, productivity is taken to be synonymous with labour productivity. This is because it is a simpler concept to estimate and it is a rough measure of the effectiveness with which we use the most important factor of productionlabour (Business Week, 1975). However, it is noteworthy that productivity is not determined by the efforts of labour alone, but in combination with land, capital, technology, management and even the environment.

\subsection{Measurement of Productivity}

The productivity of labour can be measured either as output per operator or output per manhour, expressed in money value (economic productivity) or in quantities (physical productivity). Because of the heterogeneity of output, it is more usually expressed in value terms which, for the manufacturing sub-sector, is easily calculated from ex-factory prices of finished products, estimated value of semi-finished products and other works and services of an industrial nature. When productivity is measured in physical units, the following formulae can be used to calculate productivity index: 


$$
X_{t}=\frac{Q_{t}}{Q_{0}} \div \frac{L_{t}}{L_{0}}
$$

Given that

$\mathrm{X}_{t}=$ productivity index

$\mathrm{Q}=$ Output in physical units

$\mathrm{L}=$ labour inputs

$\mathrm{t}$ and 0 are current and base periods respectively.

On the other hand, if the value of output is used to measure productivity, the following formula is used:

$$
X_{t}=\frac{P_{0} Q_{t}}{P_{0} Q_{0}} \div \frac{L_{t}}{L_{0}}
$$

Where $\mathrm{P}_{0}$ is the base period unit price of output and other variables are as defined above.

\subsection{Productivity in the Nigerian Manufacturing Industry}

Perhaps owing to the complexities involved in constructing productivity index, there is little or no data on productivity levels in the Nigerian economy in general and the manufacturing sector in particular. Ad hoc studies conducted during 1989 indicated that, on the average, there was little rise in productivity (Enisan and Akinlo, 1996). In Oshoba's study (1989) on food and basic metal industries, only 30 per cent of respondents indicated they had rising productivity. About 11 per cent recorded no growth, while more than half, 57 per cent, recorded declining productivity levels. In the same vein, the Manufacturers Association of Nigeria (MAN) confirmed that the general trend in productivity in industry was negative in 1989. Indications are that the situation has worsened since then.

In the absence of data on productivity in the sub-sector, data on other indicators of performance can be reviewed. These include manufacturing production annual growth rate, capacity utilization rate and the sub-sectors' share in the gross domestic product (GDP). From Table 1, it can be seen that growth rate in the sub-sector was relatively high in the period 1966-75 at an annual average of 12.9 per cent. This reflected the importance which the government attached to manufacturing activities and the adoption of import substitution industrialization strategy from independence which resulted in the establishment of many consumer goods industries, including soft drinks, cement, paints, soap and detergents. Growth in the sector expanded in the period 1976-85 with the establishment of more import substitution industries, with an annual average growth of 18.5 per cent. The oil boom of the era which provided enough foreign exchange for the importation of needed inputs - raw materials, spare parts and machinery - provided the impetus for this phenomenal growth. However, with the collapse of the world oil market from the early 1980s and drastically reduced foreign exchange earning capacity, the sub-sector was no longer able to import needed inputs. Hence, manufacturing output growth fell drastically to an annual average of about 2.6 per cent during the period 1986-98, even with the introduction of SAP in 1986. In fact, for the period 1993-98, growth in the sub-sector was negative.

Capacity utilization rate followed the same downward trend, from an annual average of 53.6 per cent in the period 1981-85 to 41.1, 35.4 and 31.8 per cent during the periods 1986-90, 1991-95 and 1996-98. In addition, the sectors' share in the gross domestic product fell persistently, from 9.2 per cent in 1981-85 to 8.3 per cent for period 1986-90, 7.5 per cent in 1991-95 and 6.3 per cent in 1996-98. These negative trends in the performance of manufacturing production cannot but 
indicate falling productivity. The average growth of 2.6 per cent during the SAP period fell short of the expected rate of at least 8 per cent needed to put the sector on the path of recovery. Its stunted growth constrained the capacity of the reform process to pull the economy out of recession. In addition, capacity utilization rate at about 30 per cent is low to make for profitable operations estimated at about 50 per cent. Its share of about 6 per cent of GDP is also poor when compared with between 20 and 40 percent in many industrialized and industrializing nations. Worst still, it is not encouraging when it is recognized that over 60 per cent of the nation's foreign exchange earnings is allocated to a sub-sector that contributes only about 6 per cent of the GDP.

\subsection{Lingering Problems of the Manufacturing Sector}

High productivity in the Nigerian manufacturing sector has been constrained by many factors which include the following:

(a) Low Level of Technology: This is perhaps the greatest obstacle constraining productivity in Nigeria as developments in technology and innovations are the primary forces propelling industrialization today. New processes and procedures of doing old things, and automation have revolutionized the manufacturing industry and multiplied productivity in the industrialized nations. Unfortunately, industries in Nigeria cannot acquire modern machines that have reduced processes. Most of them, especially textiles, cement, bakery, leather, paper manufacturing and many others are all producing with machinery that were procured in the 1960s and 1970s, giving rise to frequent breakdown and reduction in capacity utilization rates. Low technology is responsible for the inability of local industry to produce capital goods such as raw materials, spare parts and machinery, the bulk of which are imported. Hence there is very low value added and low productivity.

(b) Low Level of Capacity Utilization Rate: Capacity utilization rate in the manufacturing sector is between 30 and 40 per cent, indicating gross underutilization of resources. This has been blamed largely on frequent power outages, lack of funds to procure inputs, fallen demand for manufactures and frequent strikes and lockouts by workers and their employers.

(c) Low Investments: Lack of funds has made it difficult for firms to make investments in modern machines, information technology and human resources development which are critical in reducing production costs, raising productivity and improving competitiveness. Low investments have been traced largely to banks unwillingness to make credits available to manufacturers, owing partly to the mis-match between the short-term nature of banks' funds and the medium to long-term nature of funds needed by industries. In addition, banks perceive manufacturing as a high-risk venture in the Nigerian environment, hence they prefer to lend to low-risk ventures, such as commerce, in which the returns are also very high. Even when credit is available, high lending rates, which were over 40 per cent at a time, made it unattractive, more so when returns on investments in the sub-sector has been below 10 per cent on the average.

(d) High Cost of Production: Since the introduction of SAP, high and increasing cost of production has been recorded by most business organizations as a major constraint on their operations (CBN Business Surveys). Increased cost, traced largely to poor performing infrastructural facilities, high interest and exchange rates and diseconomies of scale, has resulted into increased unit price of manufactures, low effective demand for goods, liquidity squeeze and fallen capacity utilization rates.

(e) Inflation: which can be described as persistent increase in the general price level constitutes a disincentive to saving for future use and thereby retards investments and growth. It also encourages speculative activities and diverts resources from productive ventures. 
(f) Poor Performing Infrastructure: Poor performance of infrastructural facilities, characterized by frequent disruption in electric power and water supplies and inefficient telecommunication and transportation systems, is a major constraint on productivity. As firms have to invest huge capital to provide alternative infrastructural facilities to run their businesses, enterprises are forced to carry high cost structure which reduces efficiency and results in loss of competitiveness for their products.

\subsection{Achieving High Productivity in the Nigerian Manufacturing Industry}

High productivity in the Nigerian manufacturing industry is a necessary condition for the sectors' recovery, achieving competitiveness, boosting the GDP and uplifting the standards of living of the people. Achieving high productivity will require a frontal attack on the problems that were discussed in the previous section. The steps that must be taken will include the following:

\section{(i) Upgrading of Technological Capacity}

The manufacturing sector needs to improve productivity through upgrading of its technologies. Technology can help to improve productivity in four major ways: better machinery that can reduce production time and costs; better methods and process controls; breakthrough into completely new ways of doing things and product designs that can improve competitive edge and reduce costs. Most machines that are now in use are obsolete and the cost of maintaining them is very high. They should be replaced with modern machines that have better product designs and faster in processes. Computerization of processes and procedures should be embarked upon to save time and costs. The machine tools industry at Oshogbo which was designed to produce industrial machinery should be completed and made functional so that the economy will depend less on imported machinery and equipment. Simultaneously, building local capacity to produce appropriate technology should be encouraged through continuous on the job training, enhanced research and development efforts and the promotion of technological education in the school system.

\section{(ii) Reducing Cost of Production}

Controlling production costs should be given priority attention in productivity management. It should aim at reducing waste and optimizing the use of resources. Adoption of strategic planning is one sure way of reducing costs and boosting productivity. This is a medium to longterm framework for allocating resources, putting the external environment into consideration. It starts by evaluating the organizations current products, processes and procedures with the aim of determining strengths and weaknesses; sets new targets, finds the gaps and designs measures to fill them. One major objective of strategic planning is to reduce cost through the re-engineering of the operations of the organisation. Work study is also used to reduce costs and boost productivity. It involves analytical study of work processes and procedures for the purpose of knowing exactly what has to be done; the optimum conditions of work in terms methods, layouts, batch size, equipment, etc. (Akinyemi, 1983). A careful application of works study helps to reduce ineffective operations or uneconomic processes and makes for better planning and optimum costing; as well as good control and reward systems.

\section{(iii) Increasing Investments}

Effective investments make for growth and productivity. Capital investments are needed to acquire modern machinery and equipment and appropriate technology; as well as upgrade the quality of the labour force and the environment. This will require a lot of funds which is difficult to source from the banking system. A lot need to be done to solve the problem of capital finance. Currently, the Bankers Committee is working on a proposal which will require banks to set aside 
10 per cent of their yearly profits for equity investments in small scale industries. This will be complemented with increased bank funding if the government can set up a credit guarantee scheme which will share in the risk of lending to the manufacturing sub-sector. Popularization of the use of the capital market for long-term financing is also necessary.

(iv) Reducing Dependence on Imports

Reducing dependence on imports for industrial goods will have the impact of cutting cost in the long-run, increasing value added and boosting productivity. This will call for improved research and development efforts that are demand driven and the rehabilitation of the core industrial projects (CIPs) most of which have closed down. The CIPs were established by the government to produce raw materials, spare parts and machinery for downstream industries. The optimum solution to their problem would be privatization.

(v) Stimulating Demand for Manufactures

Currently, most firms have their warehouses filled with finished goods, owing to low demand. Salaries and wages have just been increased in the public sector with intention that the private sector will follow suit. This will, all things being equal, boost aggregate demand in the economy, substantially reduce the pile up of finished goods and induce expansion in manufacturing capacity utilization rate. For the economy to realize the full benefits of the wage increase, the current influx of imported goods must be checked.

\section{(vi) Rehabilitation and Development of Infrastructural Facilities}

Epileptic electric power and water supplies, as well poor telecommunication and transportation services which currently constrain industrial operations should be given priority attention by the government. There is urgent need to rehabilitate and expand them to aid industrial recovery and growth. Good infrastructure raises productivity and lowers production costs. It has been shown that a 1 per cent increase in the stock of infrastructure is associated with a 1 per cent expansion in the gross domestic product (World Bank, 1994). The most effective way of dealing with the problems of infrastructure is to partially privatize the facilities in such a manner that the public sector will own minority holdings, not more than 20 per cent.

\subsection{Empirical Review}

Baldwin and Clark (1992) comment that investments are necessary to achieve superior performance in terms of speed, quality, flexibility and innovation. But, companies fail to invest in capability building as they do not have the objective tools to value the embedded capabilities. The authors conclude that managers must look beyond the present competitive environment to the capabilities that will deliver future advantage and target their investment programmes to create those organizational assets. The size of the firm, in terms of its stock of assets, also plays an important role in the future growth of the firm.

Competitive advantage depends on the stock of resources and capabilities of the firm (Grant, 1991). The ability to maximise productivity of tangible assets and the transfer of existing assets into more productive employment can provide substantial returns (Grant, 1991).

To explain the cost of implementing strategies, Barney (1986) concludes that an analysis of the external environment may not provide above normal returns to firms, as all firms have access to publicly available information, the methodology and frameworks for conducting such an analysis either with their own skills or using rented services. On the other hand, the internal analysis of the firm's existing assets and capabilities could provide the above normal returns as that internal information would be proprietary to the firm and thus would enable the firm to have better expectation of returns. Thus, a firm's internal capabilities in the productive use of 
assets may not be easily replicated and other firms may not have access to the capital to acquire such 'enabling' assets.

Schroeder, Bates, and Junttila (2002) studied the impact of internal and external learning and proprietary processes and technologies on developing competitive advantage and the performance of manufacturing plants. The authors empirically validated that internal and external learning lead to proprietary processes which are difficult to imitate and thus improve manufacturing performance.

Marwah and Tavakoli (2004) tested the effect of FDI on economic growth in Indonesia, Malaysia, Philippines, and Thailand. Using time series annual data over the period 1970-1998, they find that FDI has positive correlation with economic growth for all four countries.

Vu et al (2006) studied sector-specific FDI inflows for both China over the period 1985-2002 and Vietnam over the period 1990-2002. Using an augmented production function specification and regression methodology, they conclude that FDI has positive and direct impact on economic growth as well as an indirect effect through its impact on labor productivity. They also find that the manufacturing sector appears to gain more than other sectors from sector-specific FDI.

Li and Liu (2005) applied both single equation and simultaneous equation system techniques to investigate endogenous relationship between FDI and economic growth. Based on a panel of data for 84 countries over the period 1970-1999, they find positive effect of FDI on economic growth through its interaction with human capital in developing countries, but a negative effect of FDI on economic growth via its interaction with the technology gap.

Castejón and Woerz (2005) employed the Nair-Reichert and Weinhold (NRW) model to check whether an increase in FDI will lead to an increase in the growth rate of output, controlling for time-invariant country-specific characteristics and for other dynamic control variables in Vienna for the period of 1987-2002. Empirical evidences from this study shows that a significant and positive relationship emerges when FDI interacts with investment or export orientation.

Tang et al (2016) explored the causal link between FDI, domestic investment and economic growth in China between 1988-2003 using the multivariate VAR and ECM. Their results indicate that there is a bi-directional causality between domestic investment and economic growth, while there is a single-directional causality from FDI to domestic investment and to economic growth. They concluded that there is a higher level of complementarity between FDI and domestic resources.

\section{Research Method}

\subsection{Data}

Time series on capital investment in the manufacturing sector and output from the manufacturing sector are collected from the CBN Statistical Bulletin and the Nigerian Bureau of Statistics. Moreover, capital investment was made up of capital importation to the manufacturing sector and credit to the manufacturing sector.

\section{Measuring Manufacturing Sector Efficiency}

The ability to diagnose and measure problems of service delivery within the system is a prerequisite to designing policy reforms and decision-making institutions to improve service delivery. Unlike the specification of an assumed existing functional relationship between output/outcome and inputs/effect that the parametric approach is known for; non-parametric approach, employing outcome and effect data for all the selected entity, adopts a mathematical 
programming method in constructing an efficiency determining mechanism or frontier (Aristovnik, 2011).

\subsection{Robust Non-parametric Frontier Estimators: Order- $m$ Partial Frontiers Option}

The choice of a "partial frontier" by Cazals et al (2002) as against the full frontier, $\Psi^{\partial}$, of FDH and DEA is mainly due to the fact that the partial frontier, unlike the full frontier, has "economic interpretation" (Simar and Wilson, 2015). Also, order-m estimators do not require the assumption of convexity; hence it is considered more useful in for drawing efficiency inferences (Wheelock \& Wilson, 2003). Unlike FDH and DEA estimators, order-m estimators are not 'plagued' with dimensionality curse; as their robustness accommodates "extreme values and noise" (Wheelock \& Wilson, 2003).

\section{-Modelling Order- $m$ Partial Frontiers \\ Input-oriented Order- $m$ Partial Frontiers}

Assuming a single input or $\operatorname{cost} x$, a full frontier $\left(\Psi^{\partial}\right)$ is expressed thus:

$$
\varphi(y)=\inf \left\{x \mid \mathrm{F}_{X \mid Y}(x \mid y) \quad 0\right\}
$$

But 3.1, according to Simar and Wilson (2015), is only true when the conditional distribution function (DF) with conditioning $\mathrm{Y} \geq \mathrm{y}$ is defined thus:

$$
H_{X Y}(x, y)=\operatorname{Pr}(X \leq x \mid \mathrm{Y} \geq \mathrm{y}) \operatorname{Pr}(\mathrm{Y} \geq \mathrm{y})=\mathrm{F}_{X \mid Y}(x \mid y) S_{Y}(y)
$$

Unlike the full frontier as shown in 3.1 above, the order-m frontier estimator known for providing a "less-extreme benchmark" is shown as follows:

Assuming an integer $m \geq 1$, we define the order-m frontier as

$$
\varphi_{m}(y)=E\left[\min \left(X_{1}, \ldots, X_{m}\right)\right]
$$

Where $X_{1}, \ldots, X_{m}$ are iid draws from $\mathrm{F}_{X \mid Y}(. \mid y)$.

Cazals et al (2002) therefore computed the order-m frontier thus:

$$
\varphi_{m}(y)=\int_{0}^{\infty}\left[1-\mathrm{F}_{X \mid Y}(\mathrm{x} \mid y)\right]^{m} d x
$$

The benchmark for a unit (x.y) producing level y of outputs is the expected minimum input level among randomly selected firms $m$ producing at least output level y (Simar and Wilson, 2015).

Also, Cazals et al (2002) proved that $\varphi_{m}(y) \rightarrow \varphi(y)$ as $m \rightarrow \infty$

Extending the order-m partial frontier to a multivariate case, Cazals et al (2002) derived the order$m$ partial frontier thus:

Cazals et al (2002) first considered $m$ random draws of random variables $X_{i}, i=1, \ldots, \mathrm{m}$ generated by $F_{X \mid Y}(. \mid y)$. Next, the random set is defined as follows:

$$
\Psi_{m}(y)=\left\{(u, v) \in \quad \begin{array}{c}
p+q \\
+
\end{array} \mid u \geq X_{i} \text { for some } 1 \leq i \leq m, v \geq y\right\}
$$

Cazals et al (2002) further gave a Farrell-Debreu input oriented efficiency score of $(x, y)$ with respect to the attainable set $\Psi_{m}(y)$ as: 


$$
\theta_{m}(x, y)=\min \left\{\theta \mid(\theta x, y) \in \Psi_{m}(y)\right\}=\min _{i=1, \ldots, m} \max _{j=1, \ldots, p}\left(X_{i}^{j} / x^{j}\right)
$$

Simar and Wilson (2015) concluded that since $\Psi_{m}(y)$ is random, therefore $\theta_{m}(x, y)$ is a random variable. Finally, using the expectation of this random variable \{i.e $\left.\theta_{m}(x, y)\right\}$ Cazals et al (2002) defined the order- $m$ partial frontier efficiency score as:

$$
\theta_{m}(x, y)=\mathrm{E}\left[\theta_{m}(x, y) \mid Y \geq y\right]=\int_{0}^{\infty}\left[1-F_{X \mid Y}(\eta x \mid y)\right]^{m} d \eta
$$

\section{Output-oriented Order- $m$ Partial Frontiers}

Cazals et al. (2002) also derived the output-oriented Order- $m$ Partial Frontiers in their work (for detailed derivation see Cazals et al, 2002).

\section{Result and Discussion}

In order to achieve the objective of this paper, which is to find out how the manufacturing sector has been productive over the years due to capital investment, we subjected the data on input (i.e. foreign capital inflow to the manufacturing sector and bank credit to the manufacturing sector) to the manufacturing sector and output (i.e. contribution of the manufacturing sector to gross domestic productive) to a non-parametric analysis using the partial efficiency frontier analysis.

The result of our input-oriented efficiency scores indicates that the manufacturing sector did not exhibit consistency in terms of efficiency in converting capital investment to optimum output. Table 1 shows that the order alpha result. The result shows the quarters that is characterized by productivity of the manufacturing sector. The efficiency score 1 signifies optimum productivity of the manufacturing sector due to capital investment. The efficiency score of 1 (which implies high efficiency in converting input to output) was only evidence in seven (7) quarters. This implies that the manufacturing sector was mostly unproductive during the period the forms the focus of this paper. It was also observed that the manufacturing remained unproductive consistently between the first quarter of 2015 to the fourth quarter of 2016. The mean efficiency score of 0.81 also shows that the manufacturing sector was generally unproductive in converting capital investment (i.e. input) to output. 


\section{Table 1: Order-alpha Efficiency Result}

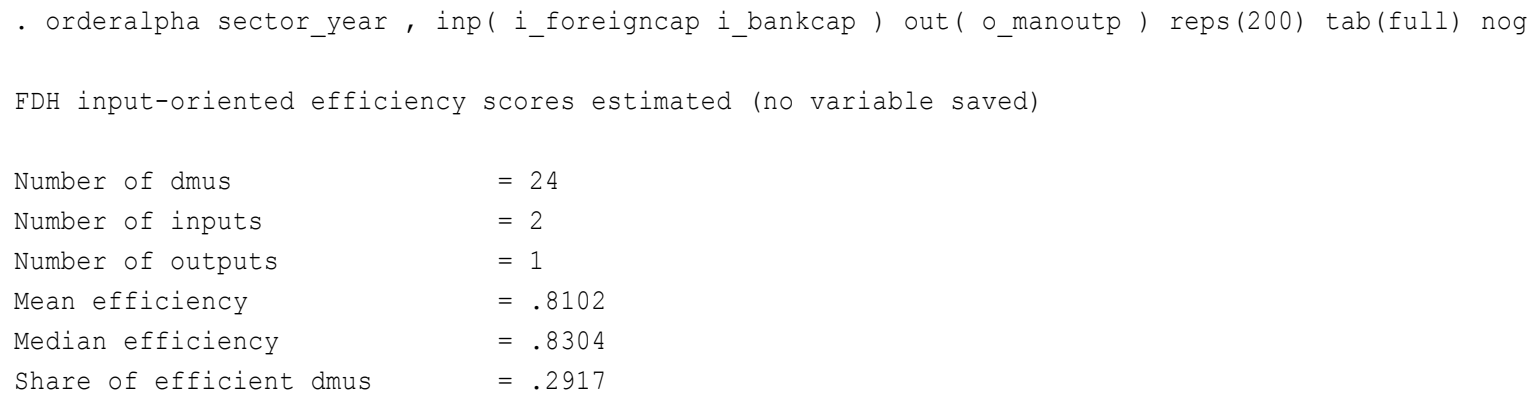

\begin{tabular}{|c|c|c|c|c|c|}
\hline $\begin{array}{l}\text { dmu } \\
\text { (sector_year) }\end{array}$ & Eff. Score & Std. Err. & z stat. & Eff. Rank & Ref. DMU \\
\hline manoutp 2011q1 & 1 & .1799798 & 0 & 1 & manoutp 20 \\
\hline manoutp $2011 q 2$ & 1 & .2584307 & 0 & 1 & manoutp 20 \\
\hline manoutp 2011q3 & 1 & .2457606 & 0 & 1 & manoutp 20 \\
\hline manoutp $2011 q 4$ & .9157271 & .1854385 & .454452 & 9 & manoutp 20 \\
\hline manoutp2012q1 & .8779337 & .0842247 & 1.449293 & 10 & manoutp 20 \\
\hline manoutp2012q2 & .9990407 & .1871565 & .0051255 & 8 & manoutp 20 \\
\hline manoutp2012q3 & .8308868 & .0992702 & 1.703564 & 12 & manoutp 20 \\
\hline manoutp2 012q4 & 1 & .2133041 & 0 & 1 & manoutp201 \\
\hline manoutp2013q1 & 1 & .1148833 & 0 & 1 & manoutp201 \\
\hline manoutp2013q2 & .8406559 & .144013 & 1.106457 & 11 & manoutp 20 \\
\hline manoutp_2013q3 & .8298589 & .068407 & 2.487187 & 13 & manoutp 20 \\
\hline manoutp_2013q4 & .7713886 & .0679196 & 3.365912 & 14 & manoutp 20 \\
\hline manoutp_2014q1 & .763342 & .0895384 & 2.643089 & 15 & manoutp 20 \\
\hline manoutp_2014q2 & .7118624 & .1101408 & 2.616085 & 16 & manoutp 20 \\
\hline manoutp_2014q3 & 1 & .0669563 & 0 & 1 & manoutp_20 \\
\hline manoutp_2014q4 & 1 & . & . & 1 & manoutp_20 \\
\hline manoutp_2015q1 & .6323313 & .1036134 & 3.548466 & 18 & manoutp 20 \\
\hline manoutp_2015q2 & .6094939 & .0799175 & 4.886364 & 21 & manoutp 20 \\
\hline manoutp_2015q3 & .6467378 & .1344657 & 2.627156 & 17 & manoutp 20 \\
\hline manoutp_2015q4 & .5802345 & .0954004 & 4.400039 & 24 & manoutp 20 \\
\hline manoutp_2016q1 & .6294503 & .0985412 & 3.760353 & 20 & manoutp 20 \\
\hline manoutp_2016q2 & .6307097 & .1045205 & 3.533185 & 19 & manoutp 20 \\
\hline manoutp_2016q3 & .5934322 & .0774447 & 5.24978 & 22 & manoutp 20 \\
\hline manoutp_2016q4 & .5824295 & .0760088 & 5.493711 & 23 & manoutp 20 \\
\hline
\end{tabular}

Note: z-Statistic is abs (Eff.Score - 1)/Std.Err. 
Table 2: Order-m Efficiency Result

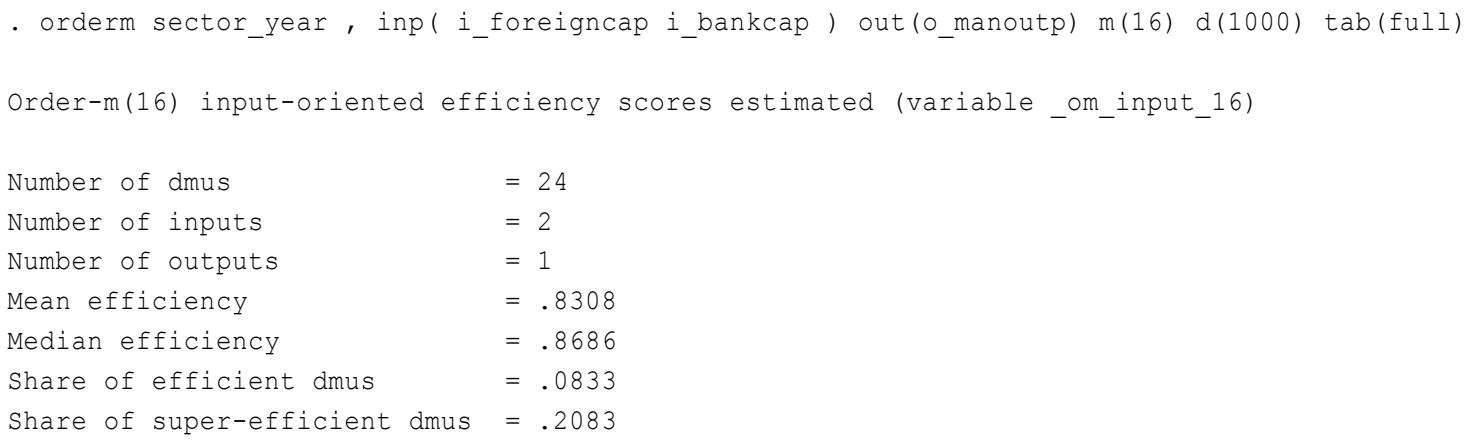

\begin{tabular}{|c|c|c|c|c|c|}
\hline $\begin{array}{l}\text { dmu } \\
\text { (sector_year) }\end{array}$ & Eff. Score & Std. Err. & z stat. & Eff. Rank & Pseudo Ref \\
\hline manoutp 2011q1 & 1.022021 & . & . & 1 & manoutp 20 \\
\hline manoutp 2011 q2 & 1.02059 & . & . & 2 & manoutp 20 \\
\hline manoutp 2011 q3 & 1.001159 & . & . & 3 & manoutp 20 \\
\hline manoutp $2011 q 4$ & .9283818 & . & . & 9 & manoutp 20 \\
\hline manoutp2012q1 & .9196644 & . & . & 10 & manoutp 20 \\
\hline manoutp2012q2 & .9990667 & . & . & 8 & manoutp 20 \\
\hline manoutp2012q3 & .8680405 & . & . & 13 & manoutp 20 \\
\hline manoutp2012q4 & 1.000828 & . & . & 4 & manoutp201 \\
\hline manoutp2013q1 & 1.000045 & . & . & 5 & manoutp201 \\
\hline manoutp2013q2 & .8691237 & . & . & 12 & manoutp 20 \\
\hline manoutp_2013q3 & .8786153 & . & . & 11 & manoutp 20 \\
\hline manoutp_2013q4 & .8255089 & . & . & 14 & manoutp 20 \\
\hline manoutp_2014q1 & .7933708 & . & . & 15 & manoutp 20 \\
\hline manoutp_2014q2 & .7350816 & . & . & 16 & manoutp 20 \\
\hline manoutp_2014q3 & 1 & . & . & 6 & manoutp_20 \\
\hline manoutp_2014q4 & 1 & . & . & 6 & manoutp_20 \\
\hline manoutp_2015q1 & .6393206 & . & . & 21 & manoutp 20 \\
\hline manoutp_2015q2 & .6438831 & . & . & 20 & manoutp 20 \\
\hline manoutp_2015q3 & .6506183 & . & . & 19 & manoutp 20 \\
\hline manoutp_2015q4 & .5965047 & . & . & 24 & manoutp 20 \\
\hline manoutp_2016q1 & .6558717 & . & . & 17 & manoutp 20 \\
\hline manoutp_2016q2 & .6542923 & . & . & 18 & manoutp 20 \\
\hline manoutp_2016q3 & .6237598 & . & . & 22 & manoutp 20 \\
\hline manoutp_2016q4 & .6139045 & . & . & 23 & manoutp 20 \\
\hline
\end{tabular}

Note: no bootstrapping; no standard errors computed

Table 2 above shows that the order- $m$ result. The result shows the ranking of quarters that is according to efficiency in productivity of the manufacturing sector. The efficiency rank of 1 (which implies high efficiency in converting input to output) was evident in the first quarter of the year 2011. This implies that the manufacturing sector was most productive during the first quarter of the year 2011. Moreover, the result also shows that the manufacturing sector was very productive between the first and third quarters of the year 2011. It was also observed that the manufacturing sector had its worst ranking during the fourth quarter of 2016. The table as shows that the lowest ranks for the manufacturing sector were evident between the first quarter of 2015 to the fourth quarter of 2016. 


\section{Conclusion and Recommendations}

The literature reviewed so far has shown that productivity of a firm or group of firms making up a specific sector is defined by the ability to efficiently convert capital investment to optimum output. Hence the need to investigate the productivity of the manufacturing sector using the input-output analysis. From the findings, this study concludes that the manufacturing sector in Nigeria has been unproductive generally when it comes to converting capital investment into optimum output. It is worthy of mention that the sector, at the earliest period covered by the study, performed well but started declining as time passes by. The implication is that the sector has not been unproductive from inception. Rather, this situation may have become evidence due to neglect of the sector by the government. It may also have been due to decay in infrastructural facilities needed to boost the productivity of the sector. This paper therefore recommends appropriate policy capable of providing the manufacturing sector with the enabling environment to thrive better and performance at optimum.

\section{References}

Adekoya, A. (1987). The Role of Government in Promoting Increased Productivity on Nigerian Farms. Proceeding of the First National Conference on Productivity, National Productivity Centre, 1991, Page 56.

Akinlo, E. A. (1996). Improving the Performance of the Nigerian Manufacturing Sub-Sector after Adjustment. The Nigerian Journal of Economic and Social Studies, Page 9.

Aristovnik, A. (2012). Relative Efficiency of Secondary Education: A Comparative Analysis of Slovena and Croatia. Paper presented at the Management, Knowledge and Learning International Conference. Available Online: http://issbs.si/press. Accessed on the 3rd of June 2015.

Baldwin, C. Y., \& Clark, K. B. (1992). Capabilities and capital investment: new perspectives on capital budgeting. Journal of Applied Corporate Finance, 5(2), 67-82.

Barney, J. (1986). Strategic factor markets: expectations, luck and business strategy. Management Science, 32(10), 1231-1241.

Castejón, C.F. and J., Wörz. (2005). Good or Bad? The Influence of FDI on Output Growth: An industrylevel analysis. WIIW Working Papers No.38.

Cazals, C., Florens,J. P.and Simar,L.(2002). Nonparametric frontier estimation: A robust approach. Journal of Econometrics, 106, pp.1-25.

Grant, R. M. (1991). The resource-based theory of competitive advantage: implications for strategy formulation. California Management Review, Spring 1991, 114-135.

Karl, H. (1988). Financial and Economic Analysis of Enterprises. International Labour Office, Geneva.

Li, X. and Liu, X. (2005). Foreign Direct Investment and Economic Growth: An Increasingly Endogenous Relationship. World Development Report,33(3), pp.393-407.

Marwah, K. and Tavakoli, A. (2004). The Effect of Foreign Capital and Imports on Economic Growth. Journal of Asian Economics, Vol. 15 pp 399-413.

Oloko, O. (1983). Factors in Labour Productivity. Proceeding of a National Conference on Productivity, Edited by Osoba, A.M. Page 7.

Osoba, A. M. (Ed.), Productivity in Nigeria. Proceedings of a National Conference organized by PPIPB and NISER, 1983. 
Schroeder, R. G., Bates, K. A., \& Junttila, M. A. (2002). A resource- based view of manufacturing strategy and the relationship to manufacturing performance. Strategic Management Journal, 23 (2), 105-117.

Simar, L.and Wilson, P. (2015). Statistical Approaches for Nonparametric Frontier Models: A Guided Tour. In: International Statistical Review, 83(1), p. 77-110. Available Online: http://hdl.handle.net/2078.1/144745. Access on the 7th of September 2015.

Tang, C.F., W.T. Tan, and I. Ozturk (2016). Energy Consumption and Economic Growth in Vietnam. Renewable and Sustainable Energy Reviews, 54, 1506-1514.

Udo-Aka, U. (1983), Measuring productivity: Issues and Problems in Productivity in Nigeria. Proceedings of a National Conference, Edited by Osoba, A.M., Page 75.

USA Business Week (1975). Special Report on Major Business Problems. Page 4.

Vu, T. and Noy, I. (2006). Is Foreign Direct Investment Good for Growth? Answers Using Sectoral Data from China and Vietnam. Unpublished.

Wheelock.,D.C. and Wilson,P.W.(2003). Robust Nonparametric Estimation of Efficiency and Technical Change in U.S. Commercial Banking. Working Paper of Federal Reserve Bank of St. Louis, 037A. http://research.stlouisfed.org/wp/2003/2003-037.pdf 
Appendix

\begin{tabular}{|c|c|c|c|}
\hline Period & $\begin{array}{c}\text { Capital Importation to the } \\
\text { Production/Manufacturing } \\
\text { Sector (\$ Million) }\end{array}$ & $\begin{array}{c}\text { Bank Credit to the } \\
\text { Manufacturing Sector } \\
\text { (N Million) }\end{array}$ & $\begin{array}{c}\text { Manufacturing } \\
\text { Output (N } \\
\text { Billion) }\end{array}$ \\
\hline $2011 \mathrm{q} 1$ & 108.30 & $1,007,399.05$ & $958,330.55$ \\
\hline $2011 \mathrm{q} 2$ & 126.12 & $910,000.42$ & $1,035,168.80$ \\
\hline $2011 \mathrm{q} 3$ & 201.25 & $1,087,403.34$ & $1,092,258.19$ \\
\hline $2011 \mathrm{q} 4$ & 125.72 & $1,053,213.33$ & $1,130,433.75$ \\
\hline $2012 \mathrm{q} 1$ & 41.01 & $1,082,856.40$ & $1,179,096.80$ \\
\hline $2012 \mathrm{q} 2$ & 198.82 & $1,088,447.45$ & $1,169,052.70$ \\
\hline $2012 \mathrm{q} 3$ & 77.61 & $1,109,775.10$ & $1,245,860.23$ \\
\hline $2012 \mathrm{q} 4$ & 231.67 & $1,068,341.70$ & $1,189,649.69$ \\
\hline $2013 \mathrm{q} 1$ & 169.44 & $1,067,487.75$ & $1,428,427.98$ \\
\hline $2013 \mathrm{q} 2$ & 116.33 & $1,082,488.64$ & $1,433,788.65$ \\
\hline $2013 \mathrm{q} 3$ & 72.59 & $1,096,572.48$ & $1,481,916.75$ \\
\hline $2013 \mathrm{q} 4$ & 32.98 & $1,179,691.40$ & $1,482,225.07$ \\
\hline $2014 \mathrm{q} 1$ & 104.07 & $1,192,126.85$ & $1,648,574.80$ \\
\hline $2014 \mathrm{q} 2$ & 107.88 & $1,278,337.60$ & $1,634,725.59$ \\
\hline $2014 \mathrm{q} 3$ & 365.10 & $1,323,025.02$ & $1,718,985.30$ \\
\hline $2014 \mathrm{q} 4$ & 366.92 & $1,500,625.10$ & $1,681,932.05$ \\
\hline $2015 \mathrm{q} 1$ & 118.36 & $1,878,091.98$ & $1,637,067.07$ \\
\hline $2015 \mathrm{q} 2$ & 51.20 & $1,909,491.64$ & $1,572,338.22$ \\
\hline $2015 \mathrm{q} 3$ & 162.42 & $1,958,451.18$ & $1,688,873.56$ \\
\hline $2015 \mathrm{q} 4$ & 91.72 & $1,736,192.99$ & $1,688,339.78$ \\
\hline $2016 \mathrm{q} 1$ & 77.77 & $1,862,589.07$ & $1,522,488.04$ \\
\hline $2016 \mathrm{q} 2$ & 89.42 & $2,058,036.94$ & $1,519,448.03$ \\
\hline $2016 \mathrm{q} 3$ & 68.25 & $2,130,441.30$ & $1,614,894.65$ \\
\hline $2016 \mathrm{q} 4$ & 67.21 & $2,215,741.07$ & $1,645,401.73$ \\
\hline
\end{tabular}

Source: Central Bank of Nigeria Statistical Bulletin (2016) and National Bureau of Statistics Annual Abstract of Statistics (2016) 